\title{
Sõimuväljendid: saatmine olematusse
}

\author{
Saša Babič \\ Eesti Kirjandusmuuseumi folkloristika osakonna teadur \\ Sasa.Babic@zrc-sazu.si \\ Piret Voolaid \\ Eesti Kirjandusmuuseumi folkloristika osakonna vanemteadur \\ Eesti-uuringute Tippkeskuse tegevjuhi ülesannetes \\ piret.voolaid@folklore.ee
}

\begin{abstract}
Teesid: Artikkel pakub võrdleva analüüsi sloveeni ja eesti keele sõimusõnadest kui emotsionaalselt tugeva laenguga väljenditest, viisakasse kõnepruuki mittekuuluvatest sõnadest, mis annavad edasi kõneleja või kiruja/sõimaja tundeid ja hoiakuid teatud olukorra/inimese suhtes. Uurimus keskendub sõimusõnade ja loitsude leksikaalsetele ja struktuurilistele sarnasustele/erinevustele võrdlevalt eesti ja sloveeni keeles. Sõim pole ainult tabusõnaline väljendusviis, vaid võib toimida funktsionaalselt nagu usundilised loitsud. Analüüsi põhieeldusena leidub mõlemas keeles nii sõimusõnades kui ka loitsudes vormel "mine X-kohta". Sihtkoht X, kuhu soovimatu isik saadetakse, on päritolukoht (nt suguorgan), mitteeksisteeriv või tähistab kaost. Kummagi keele alusmaterjali moodustab üle 50 "mine X-kohta" variandi, mille kohta esitame kategooriad. Lisaks vaatleme selle vormeli väliseid väljendeid-fraase, mis kannavad samuti ideed tõrjuda või saata keegi kusagile. Uurimuse eesmärk on välja selgitada, mil määral saab sõimuvormelite moodustamisel rääkida 1) universaalsetest joontest ja 2) kultuurispetsiifilistest piirkondlikest erinevustest.
\end{abstract}

Märksõnad: folkloor, fraseoloogia, keeleantropoloogia, loitsud, sõimamine, sõimuvormelid, tabud, vandesõnad, vandumine

\section{Sissejuhatus}

Sõimusõnad on väljendid, mis on markeeritud tabulise sõnavaraga ja kuuluvad ebaviisakasse keelekasutusse, kuigi sõimusõnadel esineb otsetähenduse kõrval piltlik tähendusväli. Eriti tähtis on asjaolu, et sõimamine ja vandumine seonduvad äärmiselt emotsionaalse kõnepruugiga, mis on eksisteerinud kogu ajaloo kestel ja on säilinud meie traditsioonilises vaimses sõnavaras, mistõttu liigitub see folklooriks. Kuigi kirumine on olnud üldinimlik nähtus ja seda on seostatud ka easpetsiifilise keelekasutusega (Gauthier 2017) ja uuritud nt tudengite keeles (Mormol 2018), on ealisus siinses käsitluses tagaplaanil, sest 
allikmaterjal on kogutud eri meetoditega ja eri earühmadelt. Uurimuse eesmärk on analüüsida sõimuväljendeid, mille puhul saadab rääkija kuulaja nn teatavasse kohta, ja esitada sõimuvormelite konstrueerimise keeleülesest universaalsusest, aga ka kultuurispetsiifilistest eripäradest tulenevad mudelid, mis seostuvad muuhulgas ka tänapäeva noortekeelega. Allikmaterjal pärineb sloveeni keelest (näited tähistatud rahvusvahelise keelekoodide standardi ISO 639-1 järgi lühendiga SL) kui lõunaslaavi keelterühma kuuluvast ja eesti keelest (näited on tähistatud lühendiga ET) kui soome-ugri keelterühma kuuluvast keelest. Vaatamata lingvistilistele ja kultuurilistele erinevustele on võrdlus võimalik neis keeltes ja kultuurides ilmneva sarnase ühiskondliku tsensuuri tõttu. Nii nagu paljudes teisteski kultuurides, on sloveeni ja eesti keeles ja kultuuris vandumine ja sõimamine üsna tugeva ühiskondliku tsensuuri all, seda peetakse argikeeleski taunitavaks. Kahe indoeuroopa keelerühma keele võrdlus Euroopa lõuna- ja põhjaosast näitab, et põhiülesehitus, kategooriatesse jaotumine ja võrreldavus loitsudega on neil vormelitel sarnane, siiski leidub erinevusi mitmel tasandil sõnavarast kuni vandumise topoloogiliste mõisteteni. Sõimusõnavara lähemal uurimisel ilmneb, et (nii inimestest kui ka olukordadest) väljaajamise või tõrjumise osas saab tõmmata paralleele loitsudega, mille siht on välja ajada kurja vaimu ja haigust. Samal ajal avalduvad mõnedes sõimuvormides manamistega sarnased mõisted kord ja kaos, algupära ning tühjus. Need kategooriad näitavad, et sõimamine ei ole ainult tabudele hääle andmise võte, vaid see sarnaneb manamisega, seega järeldub, et tavapärasus ja maagia, madal ja kõrge, profaanne ja püha on kõik pidevas dialoogis vandumise tasanditega.

Vandumine ja sõimamine on uurimisteemana jäänud pikka aega põhjalikuma tähelepanuta nii seetõttu, et pole olnud selle teema kaasaegsel tasemel sihipärast uurimist, kui ka põhjusel, et on puudunud eriotstarbelised kirumisväljendite arhiivikogud. Alles 1980. aastatest on vandumine ja sõimamine (ka ropendamine) äratanud suuremat teadushuvi ning uurijad on osutanud selle valdkonna eri vormidele ja ajenditele. Kirjutises arvestame teemakohaseid laiapõhjalisi arutelusid ja andmestikke, keskendudes sloveeni ja eesti keelele.

Rahvusvahelisel tasemel on selle valla olulisemaid ja laiahaardelisemaid töid sotsioloog Geoffrey Hughesi "History of Foul Language" ("Vulgaarkeele ajalugu", 1998), mis keskendub suurelt jaolt inglise keelele, ja hiljem kirjutatud "Encyclopaedia of Swearing" ("Vandumise entsüklopeedia", 2006). Samuti Magnus Ljungi "Swearing. A cross-cultural linguistic study" ("Vandumine: kultuurideülene lingvistiline uurimus”, 2011), mis keskendub vandumise eri tasanditele sõnavarast kuni kasutuskontekstideni.

Esimene teemassepuutuv sloveeni monograafia on sotsioloog Bernard Nežmahi (1997) avaldatud doktoriväitekiri. Järgmise monograafia, mis käsitleb 
vandumistemaatikat teiste folkloori lühivormide seas, avaldas 2015. aastal folklorist Saša Babič. Ometigi võib suurt osa materjalist (osaliselt lühiarutelud vandumisest ja sõimamisest) leida teistest fraseoloogia-alastest käsitlustest (Jakop 2005; Krikmann 2000; vt ka tõrjevormelitest Õim 2007), murdeuurimustest ja -sõnaraamatutest (Ivančič Kutin 2007), slängisõnaraamatutest (Loog 1991), vandumise kogumikest (Pšajd 2005) või avatud ligipääsuga internetisõnaraamatutest, millele kasutajad saavad jooksvalt kaastööd teha, lisades põhisõnadele selgitusi (nt http://razvezanijezik.org/; http://slang.ee/).

Eesti keeles leiab vandesõnade kohta hiljutised magistritasemel uurimused, millest esimene keskendub vandesõnade kasutamisele eesti näitekirjanduses (Sutter 2017) ning teine nende tajumisele ja tõlkimisele audiovisuaalses meedias (Treiel 2016).

\section{Vandumine ja sõimamine keeles}

Vandumine ja sõimamine ${ }^{1}$ katavad laialdase paleti väljenditest, mis kannavad erinevaid eesmärke, alustades kellegi needmisest või lihtsalt lünkade täitmisest nii kõnes kui ka kirjas, et võimendada kõneleja väljendust kuni üllatuse väljendamiseni. Eesti keeles saame eristada vandumist kui kurja nimetamist või vägisõna ütlemist sõimamisest, mis on kas otseselt või kaudselt kellelegi suunatud ja mille alla kuuluvad ka manamised, sajatused, needmised, parastamised, saatmised, lakutamised ning nendega sarnased haista- ja vilista-vormelid. Seega on siinses uurimuses analüüsitavad mine-vormelid termineeritavad sõimuväljenditena. Saatmisi (mine/käi/tõmba/keri/kao X-kohta) ja sisuideelt väga lähedaseid laku- ja haista-vormeleid (laku/haista X-asja) on parömioloog Arvo Krikmann (2000) on oma käsitlustes vaadelnud ka eesti kõnekäändude vormilis-funktsionaalse alaliigina ja termineerinud kommunikatiivse, imperatiivse sõimuvormelina.

Käesoleva artikli autorite arvates on suure kasutusväärtusega ja asjakohase definitsiooni esitanud Magnus Ljung (2011: 4), kelle järgi iseloomustavad sõimamist järgmised aspektid:

1. Tabusõnu sisaldavate lausungite kasutamine.

2. Mittesõnasõnalises tähenduses tabusõnade kasutamine.

3. Põhiosa sõimamisest tugineb vormelipõhisel keelekasutusel.

4. Vandumine ja sõimamine põhinevad emotsionaalsel keelel, mille põhiline eesmärk on peegeldada või vähemalt näiliselt peegeldada kõneleja tundeid ja hoiakuid. 
Tabusid $^{2}$ võib kohata kõikjal, kus eksisteerib sõimamine, tabude püsitunnus on solvavate sõnade allasurumine või eufemistlike variantide kasutamine (Hughes 2006: 462-463). Uurimuse autorid jagavad Hughesi arvamust, et sõimamise termin tähistab tänapäeval "mistahes ühiskondlikku taktitust, mida tuleks justkui vältida" ning on omandanud tänapäeval tähenduse kui 'vulgaarne' või 'äärmiselt ebaviisakas', mitte enam 'rangelt keelatud', nagu oli kunagi. Folkloorikogud ja murdetekstid osutavad selgesti, et diakrooniliselt ei ole ei ekskrementide ega teatud kehaosade, sh suguelundite nimetamine tabu olnud. Nende nimetamine ei põhjustanud halba, mistõttu ei olnud nende kasutamise keeldu. Nad on soovimatud üksnes sünkroonsel tasandil - neutraalse referentsiaalse tähendusega lähteallika mingid omadused on projitseeritud inimesele eesmärgiga adressaati häirida, solvata, temast lahti saada, talle halba soovida jne. Tänapäeva tabu kirjeldab üldiselt midagi sellist, mida ei tohi mainida kas teatava sakraalse iseloomu tõttu (nagu Jumala nimi) või mainitu äärmiselt võika tähenduse tõttu. Inimesed kohtlevad ebameeldivaid sõnu kui tabu, kuna see on üldkäibiv sotsiaalne norm (Pinker 2007: 357). Tabusõnades kajastuvad teemad (ekskremendid, suguorganid või seksuaalakti kirjeldamine) on kahtlemata paljudele solvav, olenemata kõneleja tujust, kuigi enamik sõimusõnadest on nüüdseks "demüstifitseeritud" üksnes sõnavormideks (Hughes 2006: xxii). Sõimuvormelite seisukohast on tabuks tunnistatud termin kõnekultuuri termin ja seetõttu ka üks sõimuväljendite juurdeloomise allikas - kõnekultuuri sobimatutes sõimuvormelites asendatakse kolesõnad emotiivselt neutraalsemate, enamasti häälikuliselt sarnaste sõnadega või sisu ümberütlemisega, ainus tingimus on see, et keelekasutaja algset nn kolesõna ära ei tunneks - mine pepusse; mine sinna, kus on pime ja pinki ei ole; mine purki; mine puu taha; putkavaht; ah sa sitikas.

Euroopa keelekogukondades on sõimamise ja obstsöönsuste laad, stiil ja viited korrapäratud, sest tabusõnad muutuvad ajas. Siiski tunduvad ühed sõimuvormid püsivad ja universaalsed, samal ajal kui teised näivad olevat rohkem aja- ja kultuurispetsiifilised. Üks vandumisvorm võib eksisteerida ühes kultuuris ning samal ajal puududa teises (Nezakat-Alhossaini \& Esslami-Rasekh 2013: 518). Keelekogukondades võib täheldada sõimuväljendite varieerumist ajas, see põhineb rahvuslikul, klassilisel ja soolisel pinnal (Hughes 2006: xxi). Vandumisele ja sõimamisele on enamasti iseloomulik ketserlus (tahtlik teotus religioossete sümbolite või nimede kasutus) või profaansus - Hughes (2006: 31) liigitab suurema osa (arvatavasti nüüdisaegsest) vandumisest nende kahe kategooria alla ning käsitleb vandumist ja sõimu tabu mõiste osana. 


\section{Sõimamine ja vandumine kui kõnetegu}

Ameerika antropoloog ja keeleteadlane Edward Sapir (1921) toonitas, et keel ja kultuur on omavahelises suhtes ja võimatu on mõista üht ilma teiseta. Otseses seoses selle assotsiatsiooniga tutvustasid keelefilosoofid John Austin (1962) ja John Searle (1969) kõneaktide teooriat, milles väitsid, et inimesed mitte ainult ei too kuuldavale sõnu grammatiliste struktuuride ja sõnade seisukohalt, vaid sooritavad nende lausungitega tegusid. Austini (1962) terminoloogias on need lausungid performatiivsed tegusõnad, mis jagunevad verdiktiivideks e otsuseaktideks, eksertsitiivideks e võimuaktideks, komissiivideks e kohuseaktideks, behabitiivideks e käitumistavaaktideks ja ekspositiivideks e esitusaktideks. Behabitiivid on seotud sotsiaalse käitumisega ning sisaldavad vabandamist, õnnitlemist, tunnustamist, lohutamist, needmist ja väljakutsumist. Seetõttu on vande- ja sõimusõnad kõneteod, mida saab kategoriseerida behabitiividena, eriti kehtib see nende sõimuväljendite kohta, millega inimesi kuhugi saadetakse (nt mine põrgusse). Kuigi sõimuväljendil võib olla performatiivi või kõneteo vorm (nt kõik "mine kohta X"), pole nende kavatsus sooritada tegu, vaid väljendada tundeid. Põhjuseks on tõsiasi, et needmislausungeid ei kasutata üksnes adressaadi solvamiseks, vaid ka kõneleja enda vihast vabastamiseks. Teisisõnu ei ole perlokutiivse akti siht alati isik, kellele on suunatud needmine, vaid lausuja võib öelda vägisõnu, vanduda või kiruda ka endamisi. Seetõttu võib vandumist mõista ka teraapilise aktina, mis väljendub ilmekalt nt liikluses (Podjed \& Babič 2015).

Sõimamine on teatavat tüüpi lingvistiline käitumine ehk emotiivne kõne. Ameerika lingvisti Roman Jakobsoni järgi (1960) on sõimamine emotiivse keele osa. See koosneb n-ö "emotiivsest või ekspressiivsest funktsioonist, keskendudes adresseerijale, kes soovib väljendada oma suhtumist öeldavasse". Puhtalt emotiivset kihistust esindavad keeles hüüdsõnad. Inglise lingvist John Lyons (1981) klassifitseerib sõimusõnad “emotsionaalidena", sest neil puudub tõeväärtus ning ei ole kindel, kas sõnades lubatud karistus leiab aset või mitte. Need ütlused väljendavad üksnes viha, üllatushirmu, kurbuse ja kurtmisega seotud emotsioone. Needmine ja sõimusõnad on tihti suunatud ainult rääkijale endale, mitte kuuljale või adressaadile (Nezakat-Alhossaini \& Esslami-Rasekh 2013: 518), ega ole mõeldud solvavana, kuigi vaidlustes paistab nende ainus funktsioon olevat solvamine, ja seetõttu suhtub laiem üldsus neisse kui solvangutesse.

Kõnelejad kasutavad tihti ütluste rõhuasetuse esiletoomiseks vandumist, sagedasti kombinatsioonis teiste toonitamistehnikatega nagu pinge, intonatsioon ja hääletoon, lisaks loomulikult mittelingvistiliste nähtustega nagu žestid ja näoilmed. Sõimu lisamine sellistes situatsioonides pakub sõimajale lisatuge tabusõnade jõulisusega (Ljung 2011: 5). Viidates kasutuskontekstile: tegelik 
valik viha, üllatuse ja rõõmu vahel selgub üksnes individuaalses kõnesituatsioonis ja mõnikord isegi siis mitte. Adressaadi interpretatsioon sõltub temale kättesaadavast lingvistilisest ja mittelingvistilisest infost (Ljung 2011: 23). Paljudes keeltes näib valitsevat kõnelejate üleüldine üksmeel selles, et kõige sagedamini kasutatakse vandumisel intensiivsuse rõhutamiseks ärritus-, valuvõi üllatushüüatusi sisaldavaid kirumissõnu.

Siinses uurimuses keskendume sõimamise vormelipõhistele väljenditele ja loitsudele, milles kasutatakse imperatiivset verbivormi "mine X-kohta", mis suunab fookuse kahtlemata adressaadile.

Sellist laadi sõimusõnu on võimalik kõrvutada ühepoolsete loitsudega (eksortsism ilma historioolata; eksortsistlik loitsuhistorioola, kurja vaimu väljaajamiseks kasutatud loitsud, vt nt Grafenauer 1937): nad sisaldavad soovimatu persooni puhastamist. Sellist tüüpi sõimamist võib kuulda kõige sagedamini viha järelmõjuna, kui sõimaja püüab väljendada oma emotsiooni, saates kedagi teatavasse kohta. Seda vormi mõistetakse solvavana, kuigi seda kasutatakse üsna sageli. X-kohta saatmist saab kõrvutada solvangute vormis manamistega: see saadab soovimatu jõu / kurjuse / inimese / osa inimesest kuskile samamoodi nagu loitsimine ravis haigusest või needusest.

\section{Materjal ja uurimismeetod}

Uurimuse analüüsi aluseks on eesti kõnekäändude ja fraseologismide andmebaas EKFA, mis sisaldab sõimuväljendeid (kahjuks enamasti ilma illustreeriva kontekstita), ja Sloveenia Etnoloogia Instituudi arhiivimaterjali põhjal 2010. aastal loodud materjalikogu, mille Saša Babič koostas põhiliselt otsesuhtluse teel ja meediakommentaaride kaudu). Esmalt valiti “mine X-i” vormi sisaldavad üksused ja seejärel vormid, milles saadetakse adressaat kaudselt teistesse kohtadesse (passiivses vormis, justkui sinna viies). Kvalitatiivse tõlgendamise lihtsustamiseks kategoriseeriti materjal kolme suuremasse alljärgnevasse rühma.

\section{Loitsud versus sõimusõnad}

Geoffrey Hughes (1991: 4) seostas vandumise loitsu, manamise ja needmisega kui: "[---] vormid, mis üritavad äratada kõrgemaid jõude, et muuta maailma või toetada tõde". Samamoodi on loitsud ${ }^{3}$ loitsija/manaja ja kurjade jõudude vaheline suhtlusvorm, millega loitsija saadab sõnumeid ja seeläbi kutsub või saadab deemonlikke jõude või kurjust (Radenkovič 1982: 2; Kropej 2009: 145), 
vandumine teeb sama inimesega, kellega kõneleja ei nõustu. Vormid "mine X-i” tõrjuvad või saadavad inimesi kohtadesse, kust nad tulid või kus mitte midagi ei eksisteeri, nagu ilmneb järgnevast sloveeni loitsust needuse vastu:

Pojdite vsi vsi hudi uraki / V te visoke gore, strme pečine, / Kjer nobeden človek ne prebiva, / Nobena človeška noga ne hodi, / Tam naj bo vase pribežališče

[Minge, kõik halvad loitsud / Need kõrged mäed, järsud kaljud / Kus ükski inimene ei ela / Ühegi mehe jalg ei kõnni / Seal peaks su kodu olema (otsetõlge)] (Dolenc et al. 1999: 102).

Sarnast tendentsi kohtame erinevates eesti loitsudes, kus kurat saadetakse X-kohta (nt füüsilistesse kohtadesse, loodusesse):

Kurat mingu koplisse, üle aia uppa. I Taha tare tatresse, saadan saba metsa, pagan mingu pajusse. ${ }^{4}$

Samuti leidub tekste haiguste sõimamise kohta: nt roosi korral silitas arstija paistetanud roosi ja lausus:

Ühest kurjast oled tulnud, aga üheksakümne üheksa kurja sisse mine tagasi. / Üle üheksa jõe, üle üheksa mere ja sealt iialgi tagasi ära tule! (Kõiva 2011: 235)

Samuti sai needusega peale pandud peavalu ja kõhuvalu leevendada ainult loitsimisega, seda võib tõlgendada ka ühe vandumise allvormina "mine X-i”. Nii nagu esinevad fraseoloogias üksused ta paneb mu pea valutama (ET) / glava me boli od njega (SL); teeb mu südame pahaks / ajab oksele (ET) / želodec se mi obraca ob njem (SL), saab inimene "teha kedagi haigeks". Inimesed, kellel lasus needus, tundsid end sageli haigena, neil oli peavalu, ja selle mure vastu sai abi loitsudega.

Vandesõnad stiilis "mine X-i" võimaldavad saavutada distantsi sõimu adressaadiks oleva isiku kui kurjuse kehastusega. Vande funktsioon sarnaneb manamise funktsiooniga - isik aetakse välja, kõrvaldatakse kui deemon: oleme jutukaaslasest tüdinud, soovime, et teda ei eksisteeriks (Nežmah 1997: 131) ja et kuulaja haihtuks. Seetõttu tulebki isik eemaldada või ära saata. Selle idee väljaütlemine on ühtaegu solvang kuulajale ja katarsis rääkijale; mistõttu asub väljend talutavuse piirimail. 


\section{Haihtumise paigad}

Kohamäärus fraasivormis "mine X-i" võib olla täidetud varieeruvalt, kusjuures kõigil sihtkohtadel on erinevaid ajast lähtuvaid konnotatsioone, kuigi neid ühendab kaos, kus mitte miski elav ei eksisteeri, või kurjuse päritoluallikas (need loitsud ajavad välja ka vastupidi lugedes, aga see ei väljendu kirumises).

Vandeüksustes esitatud sihtkohti, kuhu vestluskaaslane saadetakse, saab liigitada kolme suurema alamkategooria vahel:

I. Religioossed/üleloomulikud kohad.

II. Somaatilised (sh seksuaalse alatooniga) paigad, suguorganid.

III. Mittetabulise markeeringuga paigad, mis sisaldavad vihjeid tabudele.

\section{I.}

Esimesse rühma kuuluvad väljendid on kasutusel nn taeva nimel vandumisena, mis on seotud Jumala nime ebakorrektse kasutamisega, nt: Bog ter nima rad (slov.) [Jumal ei armasta sind]; bog daj, da bi crkno gnes [Jumal, anna, et sa sured täna]; jumal sind võtku, käi kuradile, kurat sinuga (ET) jne; kristlikes kultuurides on ka tabud seotud põrgu nimel sajatamisega, suure tõenäosusega nn sõnamaagia näitena (Ljung 2011: 6) nt naj te vrag (SL) 'Kuradile!'.

Vormeli "mine X-kohta" religioossed ja üleloomulikud kohamõisted pärinevad kas paganlikest (sel juhul kohtab neid enamasti murdes, vt Pšajd 2005: 57) või kristlikest religioonidest.

Kõigil juhtudel on religioosne sihtkoht alati paik, kus väidetavalt ei ela ükski inimhing, mis kontseptuaalselt seostub kaose, tühjuse, eimiskiga, nagu põrgu või kurat põrgu sünonüümina: pojdi $k$ huicu (SL), mene helvettiin (FI), mine põrgusse / mine Ellvetsi (ET), minge kuradile (ET). Neis ütlustes eeldatakse vastaspoolelt aktiivsust, sest neid kusagile saates peaksid nad sinna justkui ise minema. Teine väljendusvõimalus eeldab inimese passiivseks muutmist ja kuradi või üleloomulike jõudude aktiveerimist. Nagu Da bi te hudic! (SL) 'Kurat sind löögu!' Perün ${ }^{5}$ aj te vdari (SL) 'Perun sind löögu'; Svarun 6 te fcesni (SL) 'Svarun sind löögu'; gron v fcesni, gron v tebej vstreli (SL) 'välk sind tabagu', kurat sind võtaks; pagan sind võtaks; saatan võtaks (ET). Need ei ole "mine Xkohta" struktuuriga vormid, kuid siiski on nende kontseptuaalne taust sama. Sedasorti vandumine muudab inimese passiivseks, kuid ta võtab siiski vastu sama väljaviskava või teda tõrjuva karistuse. Kui negatiivne üleloomulik jõud inimest vigastab, võtab see ka tema hinge kaosemaale kaasa. Niisiis viib sedasorti vandumine inimese ka metafoorselt kaosemaale.

Vandeväljendeis mainitavad kohad on jäänud paganlike religioonide pärandina kohtadeks, kus on võimalik needusest vabaneda, nagu näiteks mets: mine metsa (ET), mene metsään (FI) või isegi tühjus: mine tühja kätte, kas või tühi 
võtaks (ET), mene tyhjäksi (FI), mine soo peale / mine sohu (ET), mine lauki (FI), mine uttu / tõmba uttu. Ilmselgelt on eesti keeles säilinud solvamissõnades paganlikud mõisted viitena kohtadele, kus miski elav ei eksisteeri. Lõunaslaavi keeltes on säilinud vaid üksikud paganlikud jumalad mõningates murdekeelsetes kirumisväljendites, ja isegi seal on nende esinemine haruldane; seega annab nende paganlike jumalate nimetamine aimu saatmise sihtkohast. Transformatsiooni väljendusena ja isikust vabanemise mõttelise meetodina on oma roll ka raskemate haiguste mainimisel. Need kirumissõnad on tänapäeval äärmiselt haruldased, leitavad pigem arhiivimaterjali hulgast, nt Da bi te kuga! Kuga te paberi! (SL) 'Soovin, et katk sind tapaks!'; katk sind võtaks (ET), aga eesti keeles sõimatakse ka haiguse kaudu: kuradi neeruhaige; va neeruhaige; haige lehma sitt; kuradi kuutõbine; et sind tõbi teises ilmas samuti tabaks. Nii väljendudes soovitakse inimesele hirmsat surma ja negatiivset transformatsiooni.

\section{II.}

Erinevalt esimesest sõimusõnade allrühmast on mittereligioosne tabu piiratud sõnadega, mida peetakse vulgaarseks või piinlikuks, need on üldjuhul suguorgani rahvapärased nimetused, aga ka rahvakeelsed sõnad väljaheidete, seksuaalvahekorra ja teiste varieeruvate, hälbeliseks arvatud seksuaalsete tavade kohta (Ljung 2011: 7). Sedasorti vandumine kasutab genitaalpiirkonna vulgaarseid nimetusi, mis on tänapäeva kõnekultuuris iseenesest tabuteemad. Kirumise sihtkohtadena on need sõnad saanud aja jooksul vulgaarse konnotatsiooni. Näiteks kõigis slaavi keeltes esindatud pizda on vana slaavi sõna emaka kohta, mis sai aga vulgaarse konnotatsiooni (ainult vene keeles säilitas see sõna mõningal määral oma põhitähenduse ja nimetamise funktsiooni); kurac on kuke vana nimetus lõunaslaavi keeltes. Jebati tuleneb seksuaalvahekorra nimetamisest, aga selline rõhuasetus ei olnud eelnevalt niivõrd esil jne. Samamoodi on eesti keeles, kus nt sõna munn 'peenis' tuleneb uurali tüvevariandist "muna". Vaieldamatult on see sõnavara tabuline, kuid mingil juhul ei saa me eirata tõsiasja, et see on inimese elutegevusega tihedalt seotud.

Suguorganid on inimelu füüsiline päritolukoht ja kui keegi saadab teist tagasi neisse organitesse (rõhutades vanemaid, eriti ema: pejt v pizdo materno 'mine ema vittu', mine putsi / mine vittu / mine munni (ET), pejt v kurac (SL) 'mine munni', on ilmselge, et selle taga peitub idee saata inimene tagasi sinna, kust ta tuli. Sedasorti vandumine hakkas koguma populaarsust mitte varem kui alles 20. sajandil. Tundub, et ateismi kasvuga samaaegselt muutus asjakohaseks ja tuli kõnekeelde inimese füüsiline päritolu. Eesti keeles kuuluvad siia allrühma ka "haista X" ja "laku X" ja sloveeni keeles "suudle X" vormelit rakendavad äärmiselt variatiivsed sõimuväljendid, nagu nt haista või laku perset / hänna alt / tussu / türa / putsi / vittu. Manamisega võib seoseid leida 
kolmarvus, mis on (eriti lõunaslaavi sõimuväljendeis) tihti käibel ekspressiivsuse tugevdamiseks. Kolm kui mütoloogiline arv kannab olulist tähendust eri religioonides, uskumustes ja samuti folklooris, nt muinasjuttudes, vanasõnades, regilauludes. Loitsudes, mis ajavad sageli välja haigust või needust, kasutatakse kolmarvu: korrates samu sõnu kolm korda või isegi korrates tervet loitsu kolm korda (tihti leitav loitse pareerivates sloveeni vastuloitsudes). Ütlused nagu pojdi $v$ tri picke materine (SL) 'mine kolme ema vittu' põhinevad ilmselgelt vastuolul ja oksüümoronil, aga number kolm näib andvat neile suurema tähendusliku kandvuse. Millegipärast ei tähelda me neis kollokatsioonides peale kolme ühtegi teist arvu.

\section{III.}

Üks osa eufemisme kasutab mittetabulisi sõnu. Need sõnad on kas kontseptuaalselt mõeldud kellegi kainestamiseks või harimiseks, või siis asendavad nad algse tabusõnaga kõlalt sarnast sõna originaali irooniaga või mõne teise valikuga.

Eufemismid võivad saata inimese midagi tegema, et ta tuleks mõistusele nt mine arene põosas (ET), slaavi keeltes on nad seotud soolaga: pojdi se solit (SL) 'Mine soola ennast!'. Teisalt on nad seotud oma pea löömisega millegi vastu, mis peaks pildi klaariks tegema: Zaleti se nekam! (SL) 'Mine ja põrka kuskile'.

Nende ütlustega ei saadeta inimest sinna, kust ta on tulnud, ega kaosesse, vaid need toimivad lihtsalt teona, et puhastada oma mõistust. Seetõttu ei saa nad olla kontseptuaalselt seotud kurjuse väljaajamisega loitsimisel, isegi kui need eufemismid saadavad adressaate midagi tegema.

Teine eufemismide allrühm püsib vormelil "mine X-kohta", pidades kinni sõimusõna samast vormist: tabusõna lihtsalt asendub, nagu mine seenele (ET), mine sirtsu sohu (ET); sõida potilaadale (ET), pejt v tri krasne / tri pirovske (SL) 'mine kolme ilusasse / kolme õllesse', pojdi v pisarno (SL) 'mine kontorisse'. Nn kolesõna asendus toimub eri põhjustel, mõnel on lihtsalt tabusõnaga sarnane kõla, teistel juhtudel asendatakse see algse sõna lühendatud variandiga. Eufemismide sõnastus võib olla väga varieeruv, sisaldades teatavat taustaks olevat irooniat, nagu pojdi $v$ tri krasne (SL) 'mine kolmele suurele', pojdi $v$ tri pomuckane marjetrice (SL) 'mine kolme litsutud karikakrasse'. Peenist tähistav vulgaarne sõna kurac on tihti asendatud sõnaga klinc 'väike oda' või lühendatult lihtsalt $k^{* * *}$. Tihti kasutatud eufemism sloveeni keeles on samuti pojdi nekam 'mine kuhugi', kus inimene saadetakse kusagile ebamäärasesse kohta või ei suudeta kindlaks määrata, mis see konkreetne haihtumise koht peaks olema.

Eesti keel asendab tabusõnad kas kirjeldusega mitteräägitust, mine kassi saba alla või saates inimese nii kaugele kui võimalik (Mine kuu peale), või isegi naljatledes mine kuu peale kurke soolama $!^{10}$, või reaalse koha, aga ebareaalse 
tegevusega markeeritud mine Abruka hani lüpsma!, millel puudub igasugune seos religiooni või inimese päritolu märkiva suguorganiga. Eufemism, millel pole paralleele sloveeni keeles, on mine pane ennast põlema, mis võib olla inkvisitsiooniaegade relikt, kuid pigem viitab üldisemas mõttes väga erakordsele alalhoiuinstinktivälisele, kuid kiirele ja üpris jäägitule enesehävitamisele või -kaotamisele. Kontseptuaalselt saadab eufemism adressaadi põrgusse ja sõnavahetus võib näiliselt pehmendada väljendit, aga see on peidetult siiski sama tugev kui originaal.

Seos loitsimiste ja kolmarvu vahel ilmneb tihti eufemismides, mida asendavad sõnad on foneetiliselt kuidagi sarnased algupäraste tabusõnadega pojdi $v$ tri pomuckane marjetrice (SL) 'mine kolme laiaks litsutud karikakrasse' või mine kus kolmas, kao kus kolmkümmend (ET), kus on ilmselge ellips.

\section{Kokkuvõtteks}

Kõigis keeltes leidub sõimu- ja vägisõnu tugevaks mittenõustumise väljenduseks või vastuhaku rõhutamiseks. Ei ole üllatav, et need sõnad pärinevad tabusõnavarast, mis rikub suhtlusreegleid, tabusõnade kasutamine tõmbab tähelepanu ja avaldab samal ajal teraapilist mõju (Ljung 2011; Podjed \& Babič 2015). Enim ilmneb tabusõnade kasutamine seoses sõimamise või vandumisega. Sõimusõnad ongi aegade vältel pärinenud tabusõnavarast. Keelatud kontekstidest pärit mõistete ja sõnade tarvitamine lisas väljenduslaadile intensiivsust. Kuigi vandumine ja sõimamine rikuvad suhtlustava ja tabud viitavad pühadele nimedele (Hughes 2006: xvi), on see eri keeltes jätkuvalt väga tavaline. Eri aegade ja piirkondade sõimuainest uurides saame paremini aru ühiskonna sügavamatest tasanditest.

Tänapäeva noortekeeles teenib edukalt tabulisuse neutraliseerimise eesmärki netikeele ehk omamoodi kirjaliku kõnekeele rohke lühendirohkus. Nii ei kirjutata roppe sõimuväljendeid sotsiaalmeedias ja sõnumivahetusprogrammides suheldes välja, vaid piirdutakse lühenditega (vt ka Voolaid 2009). Üks populaarsemaid on just "mine X-kohta" vormelit rakendav $m v$ 'mine vittu', $m p$ 'mine perse', $\mathrm{mm}$ 'mine metsa' ja sellised lühendid on kandunud ka suulisesse keelde. Kohati toimivad need noorte salakeelena - vanem põlvkond (nt pedagoogid) lihtsalt ei tea, mida need lühendid või ingliskeelsed slängiroppused (eesti kooliõpilastelt kogutud pärimuse hulgas on ka küllalt ingliskeelseid, nt sodd off and die 'tõmba uttu ja sure') tähendavad, ja nii saab vanemat põlvkonda selle enda kuuldes karistamatult teatud kohta saata.

Sloveeni ja eesti "Mine X-kohta"-vormiliste sõimuväljendite analüüs näitab, et vestluspartneri saatmiseks kasutatavate nn teatud kohtadena on säilinud 
sõimuväljendites nii teatud paganlikud paigad (Svarun, Perun, mõisted mets, soo, mäed), mis on oma religioosse tähenduskonteksti üldjuhul kaotanud, aga mõistetena leidub ka kaosele ja tühjusele viitavaid kohti, kus inimene ei ela. Sõimuväljendite korpusanalüüs osutab ilmselgetele seostele loitsimisega ehk kurjuse väljaajamise ja ka needmise rituaalidega. Ka loitsudes saadetakse needus tühjusesse või tema alglättesse, nii nagu "Mine X-kohta" sõimuväljendeis saadetakse teine inimene või vestluskaaslane kaosesse (kontseptuaalselt sobiv põrgu või kuradi asupaigana) või tagasi tema füüsilisse algallikasse (kontseptuaalselt suguorganid).

Ühtlasi paljastavad "Mine X-kohta" vormis sõimuväljendid erinevaid arusaamu inimese päritolu ja eksistentsi kohta: kui usundid ja jumalad olid pjedestaalil ja kõrgemad jõud andsid inimolenditele elu, oli jumala või kuradi mainimine sõimamisel kõige hullem patt. Teist inimest põrgu lähetades saadeti ta kaosesse ja hävingusse. Seksuaalvahekorra kui inimkeha lätte ning intiimmaailma tunnistamine inimeksistentsi olulise osana, aga eelkõige tabulisus ning vägisõnade sõnamaagiline kvaliteet tõid kaasa sõimusõnavara rikastumise intiimorganite ja seksuaalvahekorrast ajendatud mõistetega. Saates isiku tagasi emaüsasse või veelgi kaugemale ehk peenisesse, näidatakse justkui otsesõnu saatja soovi tühistada isiku eksistents.

Mõlemal juhul tegelevad "Mine X-kohta" vormis lausungid inimese päritolu, sünni ja eksistentsiga, proovides seda eitada või lõhkuda, justkui oleks hukkamõistetud inimene kellelegi kaela sadanud kurjus või needus, mida üritatakse eitades eemale ajada. Ühes inimese suremisega haihtuvad ka tema olemasolust tingitud peavalud ja haigused ja elu oleks palju lihtsam. Sellistes sõimuväljendites saadetakse inimene kas kohta, kus pole ühtegi hingelist, või põrgusse, või muusse algpunkti, nagu näiteks vittu või munni, kust iganes ta tuli, et elu saaks jälle värvid tagasi (Nežmah 1997: 131). Seetõttu on mitte-eksisteerivad ja algallikaga seotud paigad haihtumise kohana märgilise tähendusega. Mõlemad kohamõisted, nii religioossed kui ka füüsilised haihtumissihtkohad, on otseselt seotud inimeksistentsi ja sotsialiseerumisega. "Mine X-kohta" vormis sõimuväljendid on justkui katse eksistentsi mõlemapoolselt eitada.

Seoseid loitsudega võib täheldada ka kolmarvu nimetamises, mis on sõimuväljendeis tihti kasutusel ekspressiivsuse tugevdamiseks. Arv kolm on mütoloogiline ning eri religioonides ja uskumustes sümboltähenduse ja olulise väärtusega, kolmarvuline struktuur on kasutusel folklooris laiemalt, nt muinasjuttudes, lauludes, vanasõnades, loitsudes. Loitsudega aetakse haigusi välja, lausudes ühte sõna kolm korda. Ütlused, mis mainivad arvu kolm, on ilmselgelt oksüümoronid, aga see arv annab neile suurema väe ja väärtuse.

Eufemisme on kahte liiki. Üks rühm asendab tabusõnad foneetiliselt sarnaste sõnadega, mis kannavad enamasti eri tähendust. Sellised väljendid 
kinnitavad vandumise lingvistilist olemust, mille funktsioon on emotsioonide intensiivsem väljendamine, kuid mida ei võeta tavaliselt otsetähenduses. Vorm "mine X-kohta" on iseenesest niivõrd tähendusrikas, et teised sõnalised elemendid ei suuda muuta ütluse funktsiooni ja algupärane tabusõna on alati leitav. Seetõttu püsib selle allrühma eesmärk muutumatu: isikut eitada või teda tõrjuda ja välja visata.

Teine rühm eufemisme on muutnud inimese eitamise kontsepti inimese saatmiseks kuhugi, et aidata tal mõistusele tulla kas soolamise metafoori kaudu, tehes teda targemaks või äkilise šokiga löögist (zaleti se nekam (SL) 'löö ennast kuskile'). Need ütlused muutsid inimese saatmise kontseptsiooni kellegi kaosesse või selle derivaatidesse saatmisest kui karistusest, selle asemel soovitakse teatud kohta saatmisega harida, mida võib interpreteerida kui üleminekut teise vaimuseisundisse.

Kahe keele võrdlus kinnitab, et sõimusõnad on kui kollokatsioonid, esmatähtsad on fraseemid ja nende funktsioon, vähem mängib rolli sõnavaraline sisutäide. Isegi kui tabusõnad asendada teiste, sotsiaalselt vastuvõetavamate sõnadega, saavad kõik rääkijad aru nende funktsioonist ja vandumise mõttest. Sõimusõnadesse suhtutakse enamasti kui sotsiaalselt taunitud väljenditesse, isegi kui nad lisavad eneseväljendusele vürtsi. Ametlikus keeles on sõimusõnad vaikiva kollektiivse kokkuleppega keelatud. Sellegipoolest on nende tarvitamine tänapäevani rikkalik, sest paljud kasutavad neid kui "valmis eneseväljenduse tööriistu”, mõtlemata nende taga olevatele mõistetele. Ropendamise aktsepteerimine mitteametlikus keeles põhineb peamiselt tabusõnade kasutamisel, mitte nende taga peituval mõistetasandil, mis tekitab vastupidiseid olukordi, kus on parem öelda: "Pojdi v tri pomuckane marjetrice!" 'mine kolme litsutud karikakrasse', mis katab pigem tegelikku mõtet kedagi eitada pojdi v tri pizde materine 'mine kolme ema vittu', kui pojdi se solit 'mine soola ennast', mis kutsub kedagi mõistusele tulema. Üldkonstruktsioonid, kategooriad ja sõnaliigid on mõlema keele sõimuväljendites sarnased, aga ootuspäraselt esineb sõnavalikutes paikseid eripärasid (sloveeni sõimuvormelites on kasutusel nt paganlike jumalate nimed, eestiomasena saab nimetada tõrjumise tähenduses ka aktiivsele tegevusele viitavaid "haista X" ja "laku X" sõimuvormeleid). Järeldusena saab välja tuua, et ka tänapäeva noortekeele sõimuväljendite põhikonstruktsioonid on püsivad, aga konkreetsed väljendusviisid ja sõnavalik on tänapäevastunud, ka "mine X-kohta" muutused on osalt meediamõjulised (nt ingliskeelsete väljendite või nende toortõlgete lisandumine nii eesti kui ka sloveeni keeles). 


\section{Tänuavaldus}

Uurimus on seotud Eesti Teadusagentuuri institutsionaalse uurimisprojektiga IUT 22-5 ja Mobilitas Pluss järeldoktoritoetuse projektiga MOBJD33, selle valmimist toetas Euroopa Liit Euroopa Regionaalarengu Fondi kaudu (Eestiuuringute Tippkeskus - CEES, TK 145). Autorite eriline tänu kuulub Asta Õimule fraseoloogia-alaste näpunäidete ja nõuannete eest, Reet Hiiemäele ja Mare Kõivale väärt ekspertnõu eest eesti loitsude alal ning artikli anonüümsetele retsensentidele kõigi asjakohaste märkuste-soovituste eest.

\section{Kommentaarid}

1 Sloveeni keeles (ja sarnaselt teiste lõunaslaavi keeltega) pärineb preklinjati 'vanduma' vanast kirikuslaavi-keelsest sõnast klęti, millel on oletavasti indoeuroopa tüvi *klehl - tähenduses 'kiljuma, röökima, häälitsema, hüüdma, karjuma, helisema'. Eesti k vanduma 'tõotama, lubama; kiruma, siunama, kirumissõnu lausuma' põhineb läänemeresoome või läänemeresoome-saami tüvel; sõimama 'kedagi valimatute sõnadega halvustama, selliselt oma pahameelt või viha avaldama' aluseks on läänemeresoome tüvi, võib olla sama mis sõnas sõitma. Eesti keelest võib olla laenatud läti zaimot 'mõnitama' (Eesti etümoloogiasõnaraamat).

2 Sõna tabu võttis kasutusele maadeavastaja James Cook ümbermaailmareisi kirjeldavas raamatus "Voyage to the Pacific Ocean" (1777), mõiste pärineb Melaneesia keeltest ning viitab komplekssele sotsiaalsele ja antropoloogilisele tähendusele, mida väljendasid pärismaalaste kuningatele, jumalatele ja pealikele omistatud pühad esemed, mis olid lihtinimestele keelatud; üldiselt tähendaski see midagi keelatut (Hughes 2006: 462).

3 Loitsud on sõnad või rituaalid, millel on tervendav võime või võimekus saata välja kurje vaime. Loitsimine või manamine moodustab rituaali sõnadest, maagilistest esemetest ja fikseeritud manöövritest kindlal ajal ja rituaalses kohas. Enamasti jäävad loitsimissõnad saladuseks.

4 Nõidussõnad pärinevad Jakob Hurda kogust 1895. aastast, H III 25, 302 (13).

5 Perun on paganlik slaavi sõja-, kõue- ja äikesejumal, kes oli slaavi mütoloogias kesksel kohal (Kropej 2008: 46).

6 Svarun on paganlik slaavi jumal, Svarožiči isa, eeldatavasti päikesejumal (Ovsec 1991: 123).

7 Poola keeles on kombeks ka tänapäeval hüüda "Idź w cholerę!", mis tähendab 'Keri põrgu!'. Tänapäeva lõunaslaavi keeltes midagi sellist ei kohta, isegi arhiivimaterjalis esineb ainult katk.

8 Sool on lõunaslaavi keeltes kontseptuaalselt seotud tarkusega, millele annavad tunnistust: Ne imeti niti trohice soli $v$ glavi (SL) 'sul ei ole isegi tera soola peas'; $N e$ soli mi pamet! (MK) 'Ära soola mu tarkust!'.

9 Osa eufemisme on leitav vaid internetiallikatest nagu nt http:// razvezanijezik.org/ning neid ei ole võimalik taasleida mujalt. Me eeldame, et nad on väga piiratud kasutuse ja asendustega variandid. 
${ }^{10}$ Eestikeelses materjalis leidub terve hulk humoorikaid kaitsevormeleid, mis näivad olevat uuemaaegsed ja pigem parodeerivad: Mine perse kui peegel, tule välja kui neeger, oled sitaga koos kui mustikamoos, käi perse kui tuul, vahi välja kui ahv. Mõnikord võivad ka tõrjuvad vastused olla absurdsed ja isegi naljakad: Mine perse! - Kas see on sul kummist?; Mine ära! - Ise oled mära jne.

\section{Lühendid}

H - Jakob Hurda kogu Eesti Kirjandusmuuseumi Eesti Rahvaluule Arhiivis

\section{Internetiandmebaasid}

EKFA = Baran, Anneli \& Hussar, Anne \& Õim, Asta \& Õim, Katre (koost). Eesti kõnekäändude ja fraseologismide andmebaas 1998-2005 (http://www.folklore.ee/ justkui - 15.05.2019).

Razvezani jezik. Prosti slovar žive slovenščine [Untightened language. Open dictionary of live Slovenian language] (http://razvezanijezik.org/ - 15.05.2019).

Slängisõnastik (http://www.slang.ee (kasutajate endi poolt defineeritud sõnadest koosnev slängisõnastik) - 15.05.2019).

\section{Kirjandus}

Austin, John Langshaw 1962. How to do things with words. Oxford: The Clarendon Press (http://pubman.mpdl.mpg.de/pubman/item/escidoc:2271128/component/escidoc:2271430/ austin_1962_how-to-do-things-with-words.pdf - 15. mai 2019).

Babič, Saša 2015. Beseda ni konj. Estetska struktura slovenskih folklornih obrazcev. Ljubljana: Založba ZRC, ISN ZRC SAZU.

Dolenc, Milan \& Zupanič Slavec, Zvonka \& Makarovič, Marija 1999. Zagovori v slovenski ljudski medicini ter zarotitve in apokrifne molitve. Ljubljana: DZS.

Gauthier, Michael 2017. Age, gender, fuck, and Twitter: A sociolinguistic analysis of swear words in a corpus of British tweets. Thèse. Université Lumière Lyon 2.

Grafenauer, Ivan 1937. Najstarejši slovenski zagovori. Maribor: Zgodovinsko društvo.

Hughes, Geoffrey 1991. Swearing: A Social History of Foul Language, Oaths and Profanity in English. Blackwell, Oxford UK and Cambridge USA.

Hughes, Geoffrey 2006. An Encyclopedia of Swearing. The Social History of Oaths, Profanity, Foul Language, and Ethnic Slurs in the English-Speaking World. London $\&$ New York: Routledge. 
Ivančič Kutin, Barbara 2007. Slovar bovškega govora. Ljubljana: ZRC, ZRC SAZU (https://zalozba.zrc-sazu.si/sites/default/files/slovar_bovskega_govora.pdf-16. mai 2019).

Jakobson, Roman 1960. Closing Statement: Linguistics and Poetics. Sebeok, Thomas (toim). Style in Language. New York \& London: The Technology Press of Massachusetts Institute of Technology \& John Wiley \& Sons Inc, lk 350-377.

Jakop, Nataša 2005. Pragmatična frazeologija. Linguistica et philologica 14. Ljubljana: ZRC, ZRC SAZU.

Krikmann, Arvo 2000. Eesti kõnekäändude vormilis-funktsionaalseid alaliike (http:// www.folklore.ee/ kriku/PARINTRO/KKliigid.pdf - 15. mai 2019).

Kropej, Monika 2008. Od ajda do zlatoroga. Slovenska bajeslovna bitja. Celovec, Ljubljana, Dunaj: Mohorjeva.

Kropej, Monika 2009. Slovenian Charms Between South Slavic and Central European Tradition. Roper, Jonathan (toim). Charms, Charmers and Charming. International Research on Verbal Magic. New York: Palgrave Macmillan, lk 145-162.

Kõiva, Mare 2011. Eesti loitsud. Tallinn: Kirjastus Pegasus.

Ljung, Magnus 2011. Swearing. A cross-cultural linguistic study. New York: Palgrave Macmillam.

Loog, Mai 1991. Esimene eesti slängi sõnaraamat. Tallinn: Mai Loog.

Lyons, John 1981. Language and Linguistics. An Introduction. Berkley: Cambridge University Press.

Mormol, Paulina 2018. The Perception of the Offensiveness of Swear Words in L1 and L2 Among English Philology Students. Biedrzyńska, Anna \& Zięba-Plebankiewicz, Monika \& Ziętala, Grzegorz (toim). Język i jego wyzwania: język $w$ kulturze, kultura $w$ języku. Tom 1. Językoznawstwo, lk 95-107.

Nezakat-Alhossaini, Marzieh \& Esslami-Rasekh, Abbass 2013. "May bread run and you run after it": the function of cursing in Persian. Procedia - Social and Behavioral Sciences 70, lk 517-525 (doi:10.1016/j.sbspro.2013.01.089).

Nežmah, Bernard 1997. Kletvice in psovke. Ljubljana: Nova revija.

Ovsec, Damjan J. 1991. Slovanska mitologija in verovanje. Ljubljana: Domus.

Pinker, Steven 2007. The Stuff of Thought. Language as a Window into Human Nature. New York: Viking.

Podjed, Dan \& Babič, Saša 2015. Crossroads of anger: tensions and conflicts in traffic. Ethnologia Europaea: Journal of European Ethnology 45/2, lk 17-33.

Pšajd, Jelka \& Kuzmič, Franc 2005. Še zdaj, n ate sveti den, moreš Preklinjati? Psovke in kletvice iz Pomurja in Porabja. Murska Sobota, Ljubljana: Pokrajinski muzej \& ZRC, ZRC SAZU.

Radenković, Ljubinko 1982. Narodne Basme I Bajanja. Niš: Udruženi izdavači - IRO Gradina/Priština: Udruženi izdavači - NIRO Jedinstvo/Kraguevac: Udruženi izdaviči NIRO Svetlost. 
Sapir, Edward 1921. Language: An Introduction to the Study of Speech. New York: Harcourt, Brace (http://www.ugr.es/ fmanjon/Sapir,\%20Edward\%20-\%20Language,\%20 An\%20 Introduction\%20to\%20the\%20Study\%20of\%20Speech.pdf - 15. mai 2019).

Searle, John R. 1969. Speech Acts: An Essay in the Philosophy of Language. Berkley: Cambridge University Press.

Sutter, Kadi 2017. “Sellist sõna sinu suust mina seltskonnas ei talu!”. Vandesõnade kasutamisest eesti algupärase näitekirjanduse põhjal. Magistritöö. Tallinn: Tallinna Ülikool.

Treiel, Liis 2016. Vandesõnade tõlkimine ja tajumine audiovisuaalses meedias. Magistritöö. Tallinn: Tallinna Ülikooli humanitaarteaduste instituut.

Voolaid, Piret 2009. Lühendite alternatiivsed tõlgendused - rahvahuumor ja erikeel. Langemets, Margit \& Metslang, Helle \& Sepper, Maria-Maren \& Argus, Reili (toim). Eesti Rakenduslingvistika Ühingu aastaraamat = Estonian Papers in Applied Linguistics. Tallinn: Eesti Rakenduslingvistika Ühing, lk 345-363 (doi: 10.5128/ERYa5.23).

Õim, Asta 2007. Tõrjevormelid kui kõnekäänuliik. Kõiva, Mare (koost) \& Kronberg, Janika (sarja peatoim). Paar sammukest XXIII. Eesti Kirjandusmuuseumi aastaraamat. Tartu: Eesti Kirjandusmuuseum, lk 117-138 (http://www.folklore.ee/rl/pubte/ee/ araamat/2007/5astaoim.pdf - 23. mai 2019).

\title{
Summary
}

\section{Swearing: Dissolution into nothingness}

\author{
Saša Babič \\ Research Fellow \\ Department of Folkloristics, Estonian Literary Museum \\ Sasa.Babic@zrc-sazu.si

\section{Piret Voolaid} \\ Senior Research Fellow \\ Executive Manager of the Centre of Excellence in Estonian Studies \\ Department of Folkloristics, Estonian Literary Museum \\ piret.voolaid@folklore.ee
}

Keywords: incantation, folklore, linguistic anthropology, swearing, taboo words

This study comparatively analyses swearing material in the Slovenian and Estonian languages in order to show the lexical and structural similarities/differences between swearing and incantations present in the material and to argue that swearing is not only a way to give voice to taboos, but is similar to incantations. The basic premise underlying the analysis is the existence of the "go to X" formula found both in the material and in the two genres analysed. Place $\mathrm{X}$ is the place of origin, non-existence or chaos to which the unwanted is sent. There are more than 50 different variants of the formula "go to X" that we can detect in both Estonian and Slovenian languages; in addition, we 
consider the phrases which carry the idea to fend off someone or send them somewhere, but they are in a different formulation.

The adverbial slot in the phrase 'go to X' may be filled by a variety of expressions, all of which have had different connotations throughout time, although they are connected with chaos, in which nothing living exists, or the place of origin to send the evil back to from where it came (spells are also expelled by counting back, but it does not reveal in swearwords). In swearing we can specify three major groups of mentioned places to which one expels another person: 1) places linked with religion and the supernatural; 2) sexual and reproductive organs as a place of extinction; 3) places signified by nontaboo expressions that connote taboo words.

The analysis of Slovenian and Estonian swearing expressions with the formula "go to X" showed not only that this material has preserved some pagan gods and concepts of sacred places (Svarun, Perun, concept of forest, swamp mountains, etc.), which are not alive in religious contexts anymore, but also the concepts of places in which a human does not live, and places of chaos and emptiness, which can also be linked with incantations. These swearing formulas are similar to incantations, i.e., words and rituals to expel the evil, including curses. Incantations send the curse into emptiness or back to its origin. Similarly, swearwords with the formula "go to X" send another person into his or her origin (inherent in the physical conception), or into chaos, which is the conceptually fitting hell or devil's place. At the same time, it reveals a different concept of human origin and existence: when religion and god were on a pedestal and higher forces gave life to the human being, the worst violation was mentioning god and devil in swearing. When someone was sent to hell, he or she vanished into chaos and destruction. By accepting that a human being originates in a human body as a result of sexual intercourse, and by accepting the world of intimacy as an important part of human existence, swearing gained lexis from the field of reproductive and intimate organs and sexual intercourse. Sending the person back into mother's uterus or even further, into the penis (which would be pre-conception period, pre-existence), can show us the sender's aim to negate the existence of that person. In both cases utterances with the formula "go to X" deal with the person's origin, birth, and existence, trying to negate him or her or to fend them off, as if the "persecuted person" were the evil, a curse which has been brought upon someone and needs to be expelled; we exorcise the person, trying to negate him or her. With his or her death, all the headaches and illnesses originating from them would vanish; our life would become nicer and calmer. With these swearwords a person can be expelled either to the place where no (religious/Christian) soul exists, like hell, or into their point of origin, with the idea that if they had not been born, if they returned to cunt or dick, wherever they came from, life would gain colours again (Nežmah 1997: 131). Therefore, these places - either places of non-existence or places of origin - have the function of places of dissolution. Both concepts of these places send one into nothingness, non-existence, where nothing living exists. What becomes obvious is the fact that in both concepts - religious or physical - places of dissolution are directly connected with the concept of our existence and socialisation. Swearwords with the formula "go to X" try to negate our existence either way. 